\title{
IbM Pengembangan Promosi Kampung Bandeng di Kelurahan Krobokan Semarang melalui Video Animasi Stopmotion
}

\author{
Ristia Kadiasti ${ }^{1}$, Thesa Resi Shila Utami ${ }^{2}$, Teguh Hartono Patrianto ${ }^{3}$ \\ 1,2,3 Fakultas Ilmu Komputer Universitas Dian Nuswantoro, Jl. Imam Bonjol 207 Semarang, \\ (024)-3517261 \\ e-mail: ${ }^{1}$ ristiakadiasti@dsn.dinus.ac.id, ${ }^{2}$ thesa.shila@dsn.dinus.ac.id, \\ teguhhp@dsn.dinus.ac.id
}

\begin{abstract}
Abstrak
Kebutuhan Promosi bagi UKM menjadi sebuah kebutuhan ditengah pesatnya persaingan perdagangan dan maraknya promosi melalui sosial media. Industri kuliner menjadi salah satu industri yang membutuhkan promosi seperti salah satunya di desa Krobokan yang ditunjuk sebagai kampung tematik Bandeng. Beberapa UKM Bandeng di desa Krobokan mengeluhkan kesulitan mereka untuk mempromosikan produk mereka dan bersaing dengan produk Bandeng yang sudah memiliki jumlah konsumen yang jauh lebih besar. Dalam usaha promosi sendiri, UKM di desa Krobokan hanya mengandalkan penyebaran leaflet dan pameran secara offline dibutuhkan adanya promosi secara online untuk memperluas informasi seperti pembuatan video yang bisa diunggah ke sosial media. Oleh karena itu, pembuatan video animasi stopmotion cut out merupakan hal yang tepat disamping karena media yang digunakan untuk animasi cutout dapat ditemukan di kehidupan seharihari, video tersebut dapat diunggah ke beberapa produk sosial media dan fleksibilitas video untuk dapat disebarkan dengan mudah. Keterlibatan warga khususnya pemuda di desa Krobokan dalam membuat media promosi sangat memiliki andil dikarenakan pemuda tersebut sangat mengenal alur sosial media dan cara menggunakannya. Hal itu mempermudah penyebaran informasi tentang keberadaan desa Krobokan sebagai desa yang memiliki sentra industri bandeng yang berakibat semakin banyak yang mengenal desa Krobokan sebagai salah satu sentra bandeng unggul di Semarang.
\end{abstract}

Kata Kunci : Stopmotion, Video Animasi, Media Promosi, Kampung Bandeng

\begin{abstract}
Small industry needs a promotional media because a necessity amidst the rapidity of trade competition and the rise of promotion through social media. The culinary industry becomes one of the industries that need promotion such as in Krobokan village that has been designated as Bandeng thematic village. Some milkfish industry in Krobokan village complain of their difficulties to promote their products and compete with milkfish products that already have a much larger number of consumers. In their own promotional efforts, small industry in Krobokan village rely solely on leaflets and offline exhibitions, and that's why small industry require online promotion to expand information such as making videos that can be uploaded to social media. Therefore, making stopmotion cut out animation video is the right thing because the media that used for cutout animation can be found in everyday life, and the video itself can be uploaded to some social media product and it can be share easily to make a prospective buyers. The community involvement, especially youth citizen in Krobokan village have a stake in making the media promotion because youth citizen are very familiar with social media and how to use it. The issue can outspread the information about Krobokan village's existence as a village that has a milkfish industry center which is gathered customer and tourist come to Krobokan village as one of the leading milkfish centers in Semarang.
\end{abstract}


Keywords : Stopmotion, Animation Video, Promotion Media, Milkfish Industry Center

\section{PENDAHULUAN}

Pengembangan kreativitas dalam inovasi sebuah produk merupakan salah satu kunci dalam meraih sukses untuk usaha yang dijalankan. Promosi setiap produk merupakan cerminan awal konsumen dalam menilai sebuah produk baik dari segi manfaat, estetika maupun kualitas produk tersebut secara langsung maupun tidak langsung. Strategi video animasi pada sebuah produk menjadi salah satu strategi kreatif dalam pemasaran yang mampu menjadi alasan dalam mendongkrak penjualan sebuah produk. Menurut Hammond (2008:8) video animasi dan brand mampu mewakili lebih dari sebuah fakta, hubungan rasional terhadap sebuah produk maupun layanan. Audio visual hadir diantara batas alasan yang masuk akal hingga sampai kepada emosi. Ragam visual berupa informasi brand name yang unik dan berbeda, tagline produk yang simpel dan berkesan, serta pemilihan audio yang tepat merupakan komposisi dalam menonjolkan citra pada sebuah produk. Melalui penentuan komposisi tepat inilah yang dapat menjadikan sebuah produk memiliki bergaining position atau nilai tawar yang tinggi dimata konsumen atau masyarakat. Perkembangan video animasi saat ini sudah memasuki tahap modern, dimana penyajianya tidak lagi ditawarkan secara konvensional melalui cerita yang sederhana melainkan ditampilkan secara kompleks dan dinamis. Banyak desain video animasi sekarang yang sudah memiliki inovasi baik dari segi bentuk, materi yang digunakan, maupun desain visual yang tidak lepas dari aspek estetika, fungsionalitas dan ergonomis. Aplikasi grafis dan video editing memiliki andil yang besar dalam era inovasi sekarang ini. Video animasi dengan tampilan desain grafis yang unik dan bercerita, banyak diminati oleh masyarakat dewasa ini, mulai dari bentuk visual dengan dominasi gambar bergerak 3 dimensi maupun stop motion.

Konten, pesan, dan material yang digunakan untuk membuat video dalam hal keperluan promosi juga perlu diperhatikan. Pasalnya tidak semua masyarakat yang ingin berpromosi menggunakan video tersebut dapat mengembangkan sarana prasarana yang ada disekitar lingkungannya. Persepsi bahwa dalam membuat video promosi harus memiliki sarana dan prasarana yang mahal harus dikesampingkan, karena kreativitas dalam membuat sebuah karya dalam hal ini adalah video promosi, tidak terbatas dengan nominal sarana prasarana yang digunakan. Namun, kemampuan menyampaikan pesan dan konten lah yang lebih diutamakan, terlebih lagi penggunaan smartphone yang menjadi sebuah kebutuhan di berbagai golongan masyarakat. Fitur smartphone yang saat ini mampu untuk mengambil foto dan merekam video tampaknya menjadi sebuah kemudahan. Subjek yang menjadi konten video juga bisa didapatkan di berbagai tempat, salah satunya adalah stopmotion dimana material yang diramu berupa material yang mudah didapatkan.

Kelemahan yang kerap ditemui oleh para UKM salah satunya adalah dalam memasarkan produknya. Penggunaan media konvensional seperti penyebaran brosur dan pemasaran dari mulut ke mulut masih menjadi andalan mereka sedangkan dunia pemasaran berkembang seiring dengan teknologi informasi. Seperti yang dikemukakan oleh Dentsu (dalam Sugiyama dan Andree, 2011:51) bahwa di era yang dibanjiri oleh informasi, banyak orang yang dengan mudah mencari informasi yang mereka inginkan. Oleh karena itu, strategi pemasaran seharusnya mengikuti seiring berkembangnya informasi dengan cara memanfaatkan dan menyebarkan informasi tentang produk atau perusahaan tersebut. Peralihan dari proses AIDA (Attention, Interest, Desire, Action) ke AISAS (Attention, Interest, Search, Action, Share) membuat dunia pemasaran beralih menjadi kebutuhan konsumen akan informasi (Sugitama dan Andree, 2011:77) Maka dari itu, pelaku usaha harus bisa menempatkan barang atau perusahaan mereka ke dalam sistem informasi dimana konsumen bisa mendapatkan informasi secepat dan sedetail mungkin.

Fleksibilitas media yang bisa digunakan dalam usaha penyebaran informasi dapat dengan mudah dimanfaatkan oleh pelaku usaha yang memiliki budget minim untuk bisa menyewa tenaga kreatif. Dengan kata lain, pelaku usaha dapat membuat sendiri konten kreatif berisikan informasi perusahaannya dengan memanfaatkan media yang mudah ditemukan kemudian menyebarkan informasi tersebut. Video Animasi Stopmotion juga menjadi salah satu jenis media yang fleksibel dari segi penyebarannya. Iklan yang menggunakan teknik animasi sangat populer karena konten yang 
diberikan sangat menghibur. Animasi juga menunjukkan pesan yang sederhana dan mudah dicerna. Berdasarkan hal tersebut, target yang disasar oleh media video animasi stop motion juga bisa lebih luas. Video animasi stopmotion memiliki berbagai macam jenis salah satunya adalah cutout stopmotion, dimana penggunaan media dengan menggunakan potongan kertas yang digerakkan frame ke frame. Pengambilan gambar juga bisa dilakukan dengan smartphone, kamera DSLR, atau kamera pocket. Kemudahan perolehan sarana dan prasarana yang dihadirkan oleh animasi stopmotion cutout ini menjadi alasan penulis untuk melakukan pelatihan dan pendampingan kepada warga desa Krobokan Semarang untuk mempromosikan desa tersebut sebagai kampung Bandeng Semarang.

\section{METODE PELAKSANAAN}

Kegiatan pelayanan dan pengabdian kepada masyarakat kepada warga desa Krobokan Semarang dalam usaha promosi desa Krobokan sebagai kampung Bandeng melalui serangkaian proses dalam mengatasi permasalahan yang harus ditangani dengan runtutan sebagai berikut :

\section{Identifikasi permasalahan dan Survey lapangan}

Identifikasi masalah yang ada diiringi dengan survey ke lapangan yaitu ke salah satu pengusaha Bandeng di desa Krobokan. Survey lapangan yang dilakukan adalah dengan wawancara dengan Bapak Petrus dengan usaha yang dimiliki yaitu "New Istichomah" yang menjual berbagai olahan dari ikan Bandeng. Bapak Petrus mengatakan bahwa kesulitan beberapa UKM yang berada di desa Krobokan adalah kurangnya jumlah pelanggan dan kalah bersaingnya dengan sentra industri Bandeng yang bertempat di pusat oleh-oleh Semarang. Selama ini, Bapak Petrus hanya mengandalkan strategi pemasaran offline seperti pameran industri kuliner yang diadakan oleh pemerintah dan penyebaran brosur. Namun pelanggan yang datang tidak menunjukkan angka yang signifikan, sehingga perlu adanya solusi untuk memasarkan produk tersebut.

\section{Persiapan Kegiatan}

Persiapan kegiatan meliputi perijinan dan menentukan target pelatihan. Target pelatihan yang ditentukan adalah pemuda warga desa Krobokan yang tergabung dalam pemuda Karang Taruna. Keterlibatan pemuda berkaitan dengan kedekatan pemuda dengan sosial media menjadi alasan mengapa pemuda Karang Taruna terpilih menjadi target sasaran pelatihan. Perijinan dilakukan ke Kelurahan Krobokan untuk pelaksanaan kegiatan dan penyewaan tempat pelatihan yaitu di Balai Desa Kelurahan Krobokan. Persiapan kegiatan juga meliputi demonstrasi pelatihan sebelum kegiatan dimulai yaitu pembuatan dummy animasi stopmotion cutout.

\section{Pelaksanaan pelatihan}

Pada proses pelatihan dibagi menjadi dua tahap, tahap awal adalah penjelasan materi tentang stopmotion dan creative thinking dimana hal tersebut merupakan pengenalan terhadap pelatihan yang akan diajarkan. Sebelum dilakukan tahap praktikum, peserta yang berjumlah 15 orang dibagi menjadi 3 kelompok. Pada tahap praktikum, dimana peserta langsung mengerjakan proses animasi stopmotion yang dimulai dengan pembuatan materi cutout dari kertas dan gambar yang sudah disediakan. Kemudian praktek pengambilan gambar menggunakan smartphone dari masing-masing peserta dengan tripod yang sudah disediakan panitia. Setelah pengambilan gambar selesai, selanjutnya dilakukan proses editing menggunakan software Adobe Premier Pro di laptop yang sudah disediakan. Setiap langkah proses praktikum tersebut selalu didampingi dan dipantau oleh pemateri. 


\section{HASIL DAN PEMBAHASAN}

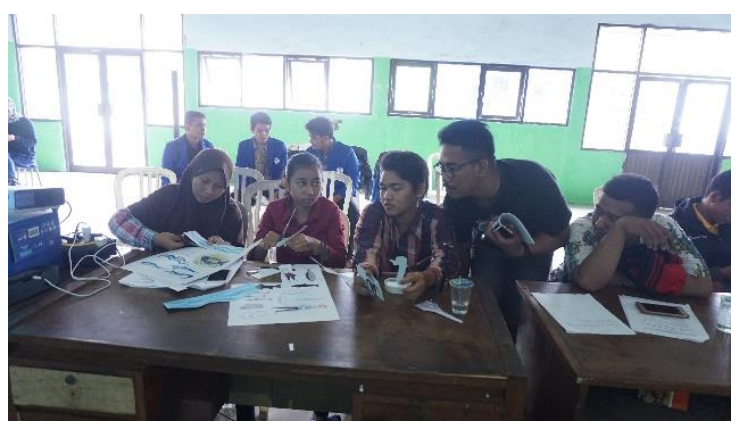

Gambar 1 Penjelasan Materi tentang Creative Thinking untuk pembuatan konten kreatif dengan berdasarkan media promosi

Hasil pelatihan kegiatan IbM pembuatan video animasi stopmotion sebagai media promosi Kampung Tematik Bandeng di desa Krobokan Semarang adalah berupa pendampingan dan pengarahan di Balai Desa Krobokan Semarang yang beralamat di Jl. Ariloka, Krobokan. Kegiatan yang terlaksana pada hari Minggu, 17 Maret 2018 ini menghasilkan video animasi stopmotion cutout menggunakan media kertas sebagai media utama pembuatan stopmotion. Pemilihan jenis stopmotion cutout dipilih karena mudahnya peralatan yang digunakan dan dapat ditemukan di lingkungan sekitar. Penyampaian materi pada tahap awal adalah pengenalan dasar tentang animasi stopmotion dan jenisjenisnya, tahap selanjutnya yaitu penyampaian materi tentang creative thinking dalam pembuatan konten kreatif, disini peserta diajak untuk mampu menggiring ide menjadi sebuah konten yang menarik dan sanggup menggiring calon pembeli ke dalam sebuah materi produksi iklan.

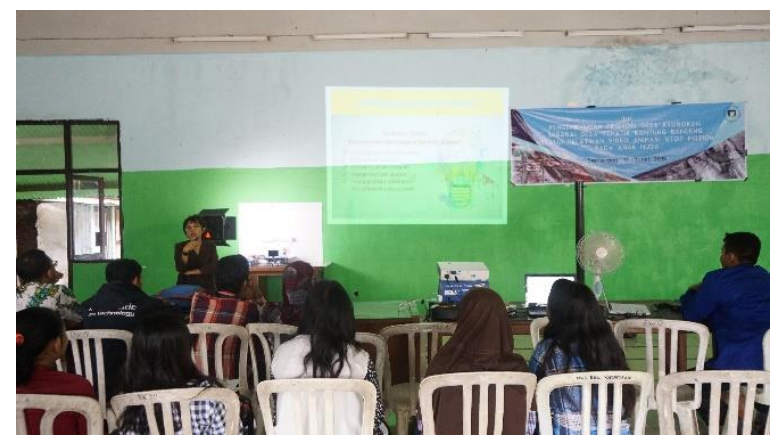

Gambar 2 Peserta membuat media animasi stopmotion cutout dengan media kertas yang dipotongpotong

Pada tahap praktikum, peserta diajak untuk membuat sendiri media yang akan digunakan untuk video animasi cutout menggunakan potongan kertas yang sudah disediakan oleh panitia.

Tahapan selanjutnya, peserta mulai mengambil gambar dengan menggunakan smartphone masing-masing peserta dengan bantuan tripod yang sudah disediakan oleh panitia. Tripod digunakan untuk menstabilkan pengambilan gambar sehingga frame by frame yang diambil sesuai pada letaknya. 


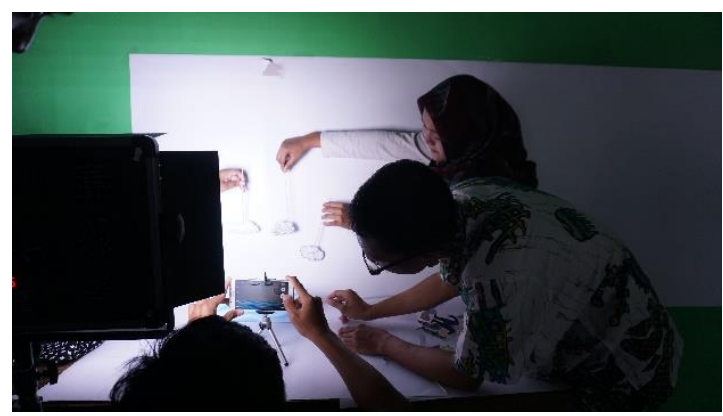

Gambar 3 Tahap praktikum yaitu proses pengambilan gambar dengan media smartphone

Setelah proses pengambilan gambar selesai, peserta mulai mengedit gambar yang tadi diambil menggunakan smartphone dengan menggunakan laptop yang sudah disediakan oleh panitia. Peserta mengedit gambar untuk dijadikan video dengan menggunakan software Adobe Premier Pro.

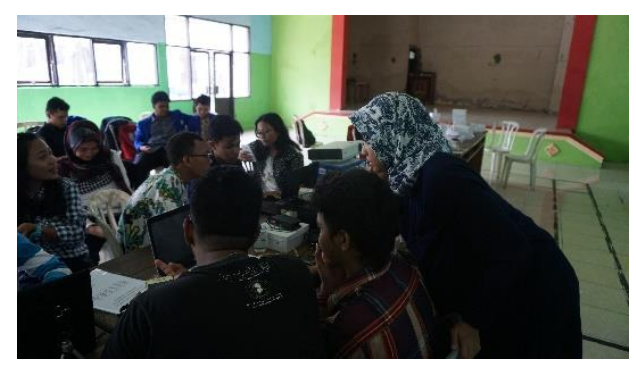

Gambar 4 Peserta melakukan proses editing video animasi stopmotion

\section{KESIMPULAN}

Pada uraian ini, penulis dapat menggarisbawahi kesimpulan menjadi beberapa poin, poin tersebut adalah :

1. Pengetahuan peserta yang sebagian besar adalah pelajar semakin berkembang, terutama pada pengetahuan tentang proses pembuatan video animasi stopmotion cutout

2. Peserta pelatihan mengerti tentang strategi promosi dengan menggunakan stopmotion dengan menggunakan media yang mudah ditemui di kehidupan sehari-hari

3. Peningkatan soft skill dalam pembuatan materi kreatif untuk media promosi berupa video iklan, peningkatan hard skill juga dapat dilihat dari kemampuan peserta dalam mengolah potongan gambar yang sudah diambil melalui smartphone kemudian mereka transfer ke dalam bentuk video melalui software Adobe Premier Pro.

\section{DAFTAR PUSTAKA}

Hammond, Kathy, 2007, Strategic Versus Tactical Nature of Sales Promotions, Journal of Marketing Communications, London, June 14 
Khan, Matin. 2006, Consumer Behaviour and Advertising Management, New Age International, New Delhi

Sugiyama, Kotaro, Andree, Tim. 2011, The Dentsu Way: Secrets of Cross Switch Marketing from the World's Most Innovative Advertising Agency, McGraw Hill Professional, New York, United States

Vilanilam, JV., A.K. Varghese, 2004, Advertising Basic! A Resource Guide for Beginners. Response Books, New Delhi 